\title{
ANÁLISE MACROSCÓPICA E MICROMORFOLÓGICA DE ESTRUTURAS SEDIMENTARES APLICADA À INTERPRETAÇÃO DE EVENTOS DE DEPOSIÇÃO DE SEDIMENTOS EM DEPÓSITOS DE BAIXA ENCOSTA NO SUL DO SEGUNDO PLANALTO DO ESTADO PARANÁ (BRASIL)
}

\author{
Gisele Pietrobelli \\ Universidade Estadual do Centro-Oeste do Paraná - Unicentro \\ gipietrobelli@hotmail.com \\ Elias Machado \\ Universidade Estadual do Centro-Oeste do Paraná - Unicentro \\ eliaspoker89@gmail.com \\ Eliza do Belem Tratz \\ Universidade Estadual do Centro-Oeste do Paraná - Unicentro \\ elizatratz@gmail.com \\ Mauricio Camargo Filho \\ Universidade Estadual do Centro-Oeste do Paraná - Unicentro \\ mcamargo12@hotmail.com \\ Wellington Barbosa da Silva \\ Universidade Estadual do Centro-Oeste do Paraná - Unicentro
} w barbosa@hotmail.com

\begin{abstract}
RESUMO
Depósitos de encostas bem preservados têm sido objeto de estudo na região sul do Segundo Planalto do Paraná. Estes depósitos apresentam-se de forma muito nítida com estruturas sedimentares primárias preservadas, ainda assim, os trabalhos que enfatizam as estruturas físicas destes depósitos são restritos, justificando a relevância deste trabalho que tem como objetivo central a interpretação dos tipos de fluxos responsáveis pela deposição dos sedimentos e processos pedogenéticos associados. Para isso, foram usadas as seguintes técnicas: levantamento de seções estratigráficas, descrição macroscópica de estruturas sedimentares em campo, análise granulométrica, análise de microscopia ótica. Para formação das estruturas de sedimentação fluxos mais vigorosos com baixa densidade foram dominantes. Entre as estruturas presentes nos depósitos de encosta predominam estruturas planoparalela, estrutura maciça e estrutura gradacional. Estruturas de deformação plástica ocorreram sob condições de ambiente tanto úmido como seco. Por dois períodos distintos, processos pedogenéticos foram responsáveis pela formação dos paleohorizontes organominerais. Nestes casos, a intensa pedogênese dominou a encosta, nas demais situações os processos deposicionais foram predominantes sobre os processos pedogenéticos uma vez que as estruturas sedimentares se encontram bem preservadas permitindo o presente estudo.
\end{abstract}

Palavras-chave: depósitos de encosta. estruturas sedimentares. paleo-horizontes.

\section{MACROSCOPIC AND MICROMORPHOLOGICAL ANALYSIS OF SEDIMENTAR STRUCTURES APPLIED TO THE INTERPRETATION OF SEDIMENT DEPOSITION EVENTS IN LOW SLOPE DEPOSITS IN THE SOUTH OF THE SECOND PLATEAU OF PARANÁ STATE (BRAZIL)}

\footnotetext{
ABSTRACT

Deposits of well-preserved slopes have been studied in the southern region of the second plateau of Paraná. These deposits are very clear with preserved primary sedimentary structures, still, the studies that emphasize the physical structures of these deposits are restricted, justiing the relevance of this work that has as Central
} 
objective is the interpretation of the types of flows responsible for sediment deposition and associated pedogenetic processes. For this, the following techniques were used: survey of stratigraphic sections, macroscopic description of sedimentary structures in the field, granulometric analysis, optical microscopy analysis. For the formation of sedimentation structures more prevaied flows with low density were dominant. Among the structures present in the slope deposits predominate flat-parallel structures, massive structure and gradational structure. Structures of plastic deformation occurred under conditions both moist and dry. For two distinct periods, pedogenetic processes were responsible for the environment formation of the Paleo-organicmineral horizons. In these cases, the intense pedogenesis dominated the slope, in the other situations the depositional processes predominated over the pedogenetic processes, since the sedimentary structures are well preserved allowing the present study.

Keywords: slope deposits. sedimentary structures. paleo-horizons.

\section{1 - INTRODUÇÃO}

Estudos desenvolvidos no sul do Segundo Planalto do Paraná mostraram que as encostas da região vêm sendo submetidas a processos alternados de estabilidade ambiental e coluviação desde pelo menos 41.490 anos A.P. As unidades coluviais colocam à mostra truncamento de camadas que sugerem recorrência de alguns processos e mecanismos de erosão. Camargo (1998), Camargo (2005), Paisani (1998), Pereira e Oliveira (2006), Oliveira et al. (2006) e Pietrobelli (2009) identificaram unidades coluviais e orgânicas recobrindo eixos de concavidades onde se instalam, em geral, processos erosivos na forma de voçorocas e túneis.

As diferentes condições ambientais, materializadas sob a forma de depósitos e paleo-horizontes organominerais, que recobrem as encostas, conduziram os estudos sobre os fluxos responsáveis pela deposição dos sedimentos em encosta localizada no município da Lapa (PR), ao Sul do rio Iguaçú.

\section{2 - ÁREA DE ESTUDO}

A área de estudo deste trabalho situa-se ao sul do rio Iguaçu, no município de Lapa (PR), abrangendo o sul do Segundo Planalto Paranaense (figura 1). Trata-se de encosta que apresenta em seu setor mais baixo, em seção de corte de estrada, nítidos níveis estratificados, intercalados com horizontes organo-minerais e estrutura de corte e preenchimento com estruturas sedimentares internas bem preservadas.

A litologia local é representada basicamente por rochas paleozoicas do Devoniano e Silurodevoniano das Formações Furnas e Ponta Grossa respectivamente, e rochas permocarboníferas do Grupo Itararé do Super-Grupo Tubarão. O ambiente em que está inserida a área deste estudo é fortemente influenciado pelas características litológicas que desempenham papel fundamental na formação do relevo local, uma vez que o Arenito Lapa, presente nas cotas mais elevadas, revela-se mais resistente à erosão e dá origem a patamares bem definidos no terreno. As encostas têm comprimento médio de $400 \mathrm{~m}$, podendo atingir $700 \mathrm{~m}$ ou mais, as maiores declividades correlacionam-se com as porções mais altas.

A encosta estudada situa-se à margem direita $(L)$ do arroio da Colher, tem 513,4 m de extensão e declividade média de $8 \%$ sendo a máxima em torno de $17 \%$. Da média para a baixa encosta ela simula uma rampa com rupturas de declive orientadas por falhamentos. No topo da vertente ocorrem arenitos que se estende da alta à média encosta, sucedidos por folhelhos, numa faixa de 12 a $18 \mathrm{~m}$. Arenito conglomerático cinzento, que constitui a unidade basal da seção, ocorre da média encosta até às margens do arroio. Fragmentos destas rochas compõem o depósito sedimentar da Seção Colher.

$\mathrm{Na}$ base da encosta, a aproximadamente $50 \mathrm{~m}$ do arroio Colher, em corte de estrada, há um afloramento em cuja face há nítida estratificação com intercalações de unidades alúvio-coluviais,

$\begin{array}{llllll}\text { Caminhos de Geografia } & \text { Uberlândia } & \text { v. 20, n. } 72 & \text { Dezembro/2019 } & \text { p. 537-559 } & \text { Página } 538\end{array}$


Análise macroscópica e micromorfológica de estruturas sedimentares aplicada à interpretação de eventos de deposição de sedimentos em depósitos de baixa encosta no sul do segundo planalto do estado Paraná (Brasil)
Gisele Pietrobelli

Elias Machado

Eliza do Belem Tratz

Mauricio Camargo Filho Wellington Barbosa da Silva

aluviais e paleo-horizontes organominerais com estruturas sedimentares internas bem preservadas. Seccionando o perfil há uma estrutura de corte e preenchimento de antiga voçoroca, com estruturas sedimentares internas bem preservadas.

Desse modo, o objeto de estudo é representado pelas estruturas sedimentares preservadas nos depósitos alúvio-coluviais, aluviais e paleo-horizontes organominerais soterrados presentes na seção, denominada de Seção Colher. O objetivo do trabalho foi identificar tipos de fluxos responsáveis pela deposição dos sedimentos e processos pedogenéticos associados. Para obter a resposta necessária, buscou-se reconhecer, através da distribuição e caracterização dos depósitos de baixa encosta e estruturas sedimentares preservadas na seção que expõe esses depósitos, os processos erosivos, deposicionais e pedogenéticos que atuaram sobre eles.

Figura 1 - Mapa de localização da área de estudo.

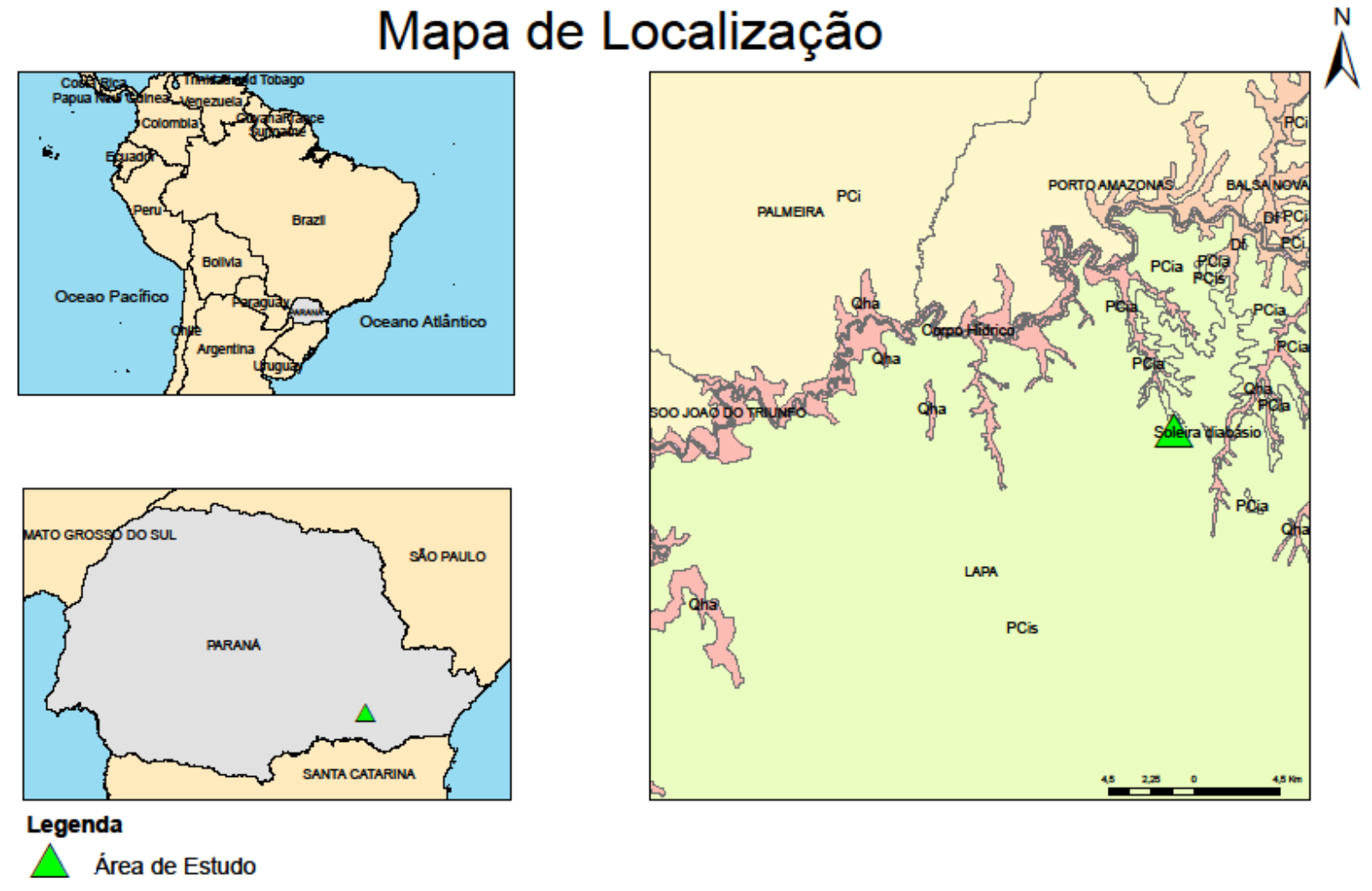

Fonte: autores.

\section{3 - MATERIAL E MÉTODOS}

O propósito de investigar o significado dos depósitos de baixa encosta, que ocorrem no interior do município de Lapa (PR), enfatizando as estruturas sedimentares preservadas, empregou-se os métodos e técnicas descritos a seguir: 
Análise macroscópica e micromorfológica de estruturas sedimentares aplicada à interpretação de eventos de deposição de sedimentos em depósitos de baixa encosta no sul do segundo planalto do estado Paraná (Brasil)
Gisele Pietrobelli

\section{4 - LEVANTAMENTO DE SEÇÕES ESTRATIGRÁFICAS}

\section{1 - Levantamento do afloramento Colher}

Em afloramento oriundo de corte de estrada, foram levantadas seções estratigráficas e descritas estruturas sedimentares. Para isso foi adotado os critérios Boggs Junior (1992) para levantamento de seções estratigráficas em campo, conforme segue:
a) determinação de mudanças laterais e verticais de litofácies;
b) medição de espessura e comprimento de unidades distintas;
c) descrição das propriedades texturais e estruturas sedimentares;
d) medição de orientação de direção de estruturas sedimentares;
e) identificação dos componentes minerais.

\section{2 - Descrição macroscópica de estruturas sedimentares em campo}

Para descrição das estruturas sedimentares foram adotados os procedimentos de Conybeare e Crook (1982), que consideram:
a) a estrutura como uma unidade;
b) as feições internas da estrutura;
c) a estrutura em relação ao material circundante e;
d) a estrutura em sua relação com as estruturas associadas.

\section{3 - Análise granulométrica}

A análise granulométrica dos materiais coletados, seguiu as orientações do método proposto pela EMBRAPA (1979), onde é combinada fases de peneiramento e de sedimentação.

\section{4 - Micromorfologia}

A análise micromorfológica visa reconhecer os constituintes minerais, petrorrelíquias, microestruturas sedimentares e feições pedológicas de solo e sedimento permitindo interpretar o seu ambiente de formação. As descrições e interpretações foram efetuadas conforme Brewer (1972), Fitzpatrick (1984), Bullock et al. (1985) e Castro (1989) e dispostas nos resultados da pesquisa.

\section{5 - RESULTADOS E DISCUSSÕES}

\section{1 - Estruturas de sedimentação}

A seção levantada apresenta 17,75 m de extensão e nela foram construídas 4 janelas ou seções estratigráficas menores para individualização das unidades deposicionais e detalhamento das estruturas sedimentares (Figura 2).

Devido a complexidade da estrutura estudada, optou-se por agrupar-se em unidades denominadas: Fragmentos de Folhelho, Areia-argilosa Cinzenta, Páleo-horizonte Organomineral 1, Páleo-horizonte Organomineral 2, Alúvio 1, Alúvio-colúvio 1, Alúvio 2, Lentes arenosas, lentes conglomeráticas, Horizonte A e Horizonte B. Estas são cortadas por estrutura de corte e preenchimento (cut and fill) da ordem de $2 \mathrm{~m}$ de largura. 
Análise macroscópica e micromorfológica de estruturas sedimentares aplicada à interpretação de eventos de deposição de sedimentos em depósitos de baixa encosta no sul do segundo planalto do estado Paraná (Brasil)
Gisele Pietrobelli

Elias Machado

Eliza do Belem Tratz

Mauricio Camargo Filho Wellington Barbosa da Silva

Nesse trabalho compreende-se sedimento como acumulação de minerais, fragmentos de rocha e solo que foram transportados e ao se acumularem, constituem os depósitos de sedimentos. Assim, o meio de transporte e o meio de deposição são os fatores mais importantes a serem considerados no estudo de estruturas de sedimentação (REINECK \& SINGH, 1980). Muitas estruturas sedimentares se originam de processos que envolvem movimento de água ou ar que ocorreram durante a deposição. Outros são formados por processos físicos posteriores à deposição inicial (BOGGS JUNIOR, 1992). Em ambos os casos tem-se estruturas sedimentares físicas ou primárias.

Quando ocorrem duas ou mais camadas de sedimentos, com natureza semelhante ou não, mas geneticamente relacionadas e superpostas, tem-se uma sequência de camadas (REINECK \& SINGH, 1980). Cinco fatores que podem determinar a ocorrência de estratificação, são eles:

a) mudança de granulação do sedimento que está relacionada às flutuações nas velocidades das correntes ou às características da(s) fonte(s) de suprimento de sedimentos; essas mudanças podem ser tão sutis que só são reconhecidas em microscópio; 
Figura 2 - Representação da Seção Colher

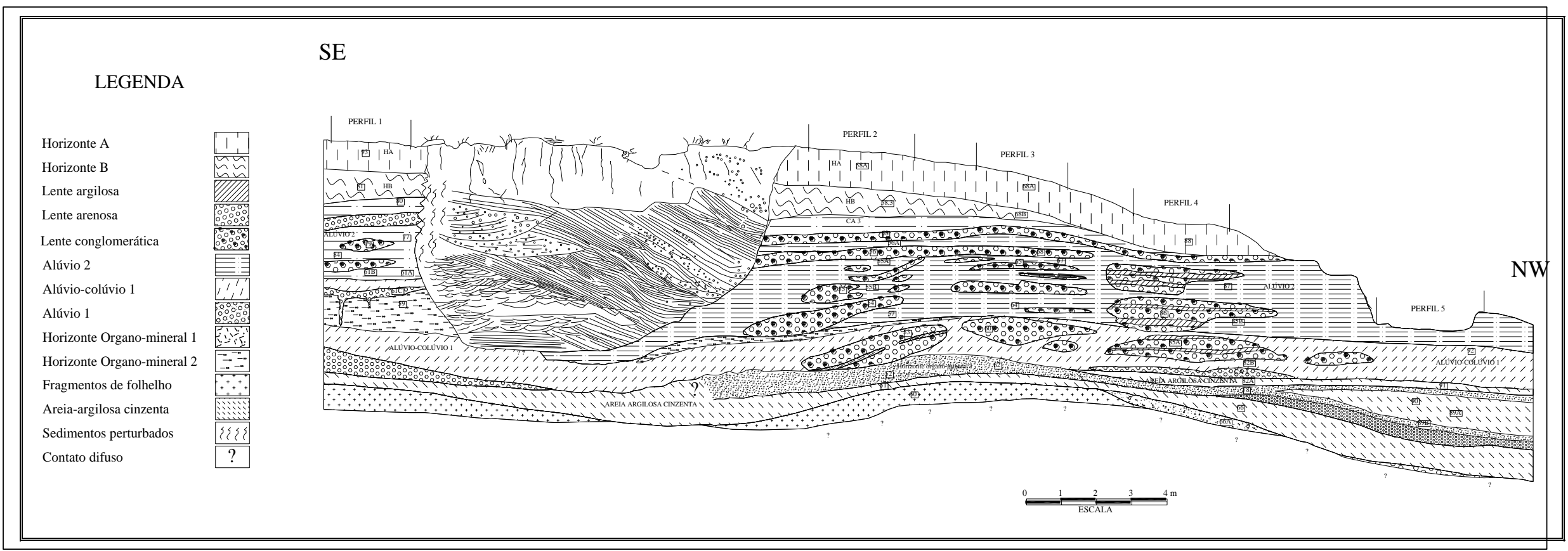


Análise macroscópica e micromorfológica de estruturas sedimentares aplicada à interpretação de eventos de deposição de sedimentos em depósitos de baixa encosta no sul do segundo planalto do estado Paraná (Brasil)

b) alteração de composição mineralógica constitui-se na causa mais óbvia da existência de estratificação e está relacionada, da mesma forma que no item anterior, com variações na velocidade das correntes ou nas propriedades das fontes;

c) mudança na morfometria das partículas que estão associadas ao grau de arredondamento ou esfericidade, podem eventualmente originar estratificação;

d) orientação das partículas inequidimensionais, que pode ocorrer em folhelhos, cuja estratificação ou fissilidade é ressaltada pela orientação dos argilominerais, que geralmente apresentam formas placóides e;

e) intercalações de lâminas argilosas podem ocorrer por intercalação de filmes argilosos que se acumulam em períodos de ausência de corrente e quando predomina a decantação (SUGUIO, 2003).

Ao se analisar sequencias de camadas ou estratos deve-se ter o entendimento de que a dinâmica de fluidos fornece a base física para discussão de transporte de sedimentos e formação de estruturas sedimentares (NICHOLS, 2000). Elas são resultantes de interações entre gravidade, características físicas do sedimento e do fluido, podendo fornecer informações importantes sobre as condições hidráulicas do ambiente de deposição (ALLEN, 1966; 1984; REINECK e SINGH, 1980; SUGUIO, 1980).

No regime de fluxo superior a resistência ao escoamento é baixa, e o transporte de sedimentos é intenso. A superfície da água encontra-se em fase com a superfície do leito e o transporte dos sedimentos dá-se em lençóis, deslocando-se os grãos individualmente, por rolamento, de maneira quase contínua corrente abaixo. Desenvolvem-se então camadas planas com espessuras correspondentes ao tamanho do grão (MEDEIROS et al. 1971; SUGUIO \& BIGARELLA, 1979).

No regime de fluxo inferior se dá alta resistência ao escoamento e baixo transporte de sedimentos. As ondulações de superfície da água não estão em fase com as ondulações dos sedimentos do leito. A resistência ao fluxo é dada pela rugosidade (roughness) das formas de leito (bed form). O transporte se dá por etapas, grãos individuais movem-se para cima até a crista das marcas de onda e em avalanche pela superfície frontal (MEDEIROS et al. 1971; SUGUIO \& BIGARELLA, 1979). A configuração do leito na zona transicional apresenta combinações dos aspectos acima descritos, com as formas de leito geralmente erráticas ou caóticas. Segundo Medeiros et al. (1971) na transição de regime de fluxo inferior para superior, as ondas de areia decrescem em amplitude e aumentam em comprimento, até o leito adquirir configuração plana.

O estudo das estruturas sedimentares preservadas em antigos canais preenchidos ou depositadas nas encostas pode constituir importante instrumento para reconstituição de mecanismos e processos pretéritos (MELLO, 1992).

Os estratos sedimentares que constituem a estrutura de corte e preenchimento (que secciona o afloramento) e suas características estão resumidas no quadro 1. 
Análise macroscópica e micromorfológica de estruturas sedimentares aplicada à interpretação de eventos de deposição de sedimentos em depósitos de baixa encosta no sul do segundo planalto do estado Paraná (Brasil)

QUADRO 1 - Síntese das estruturas sedimentares de baixa encosta da Seção Colher

\begin{tabular}{|c|c|c|c|c|c|c|c|c|c|}
\hline $\begin{array}{l}\text { Tipo de } \\
\text { estrutura }\end{array}$ & $\begin{array}{l}\text { Unidade } \\
\text { sedimentar }\end{array}$ & Subunidade & $\begin{array}{l}\text { Espessura } \\
\text { da sequência }\end{array}$ & Lâminas & $\begin{array}{l}\text { Espessura } \\
\text { do estrato }\end{array}$ & $\begin{array}{l}\text { Forma de } \\
\text { ocorrência }\end{array}$ & Fábrica & $\begin{array}{c}\text { Contato sub } \\
e \\
\text { sobrejacente } \\
\end{array}$ & $\begin{array}{l}\text { Frequênci } \\
\text { a }\end{array}$ \\
\hline & Alúvio 1 & & $4 \mathrm{~cm}$ & $\begin{array}{c}\text { Grânulos e } \\
\text { seixos + areia } \\
\text { grossa e argila+ } \\
\text { areia }\end{array}$ & $1 \mathrm{~cm}$ & Lente & $\begin{array}{l}\text { Clasto- } \\
\text { suportado }\end{array}$ & Abrupto & $x$ \\
\hline & Alúvio-colúvio 1 & & $12 \mathrm{~cm}$ & $\begin{array}{l}\text { Argilo-arenosa + } \\
\text { carbonosa }\end{array}$ & $-0,3 \mathrm{~cm}$ & $\begin{array}{l}\text { Base e } \\
\text { topo da } \\
\text { unidade }\end{array}$ & - & Abrupto & \\
\hline & Alúvio-colúvio 1 & & $28 \mathrm{~cm}$ & $\begin{array}{l}2 \text { estratos de } \\
\text { areia e grânulos } \\
\text { intercalados com } \\
\text { lâmina argilosa }\end{array}$ & $\begin{array}{l}10 \mathrm{~cm} \\
4 \mathrm{~cm}\end{array}$ & Lente & $\begin{array}{l}\text { Clasto- } \\
\text { suportado }\end{array}$ & Abrupto & $x$ \\
\hline & Alúvio 2 & & $10 \mathrm{~cm}$ & $\begin{array}{c}2 \text { camadas de } 5 \\
\text { cm com grânulos } \\
\text { e seixos }\end{array}$ & $5 \mathrm{~cm}$ & Lente & $\begin{array}{l}\text { Matriz- } \\
\text { suportado }\end{array}$ & Abrupto & $x$ \\
\hline & Alúvio 2 & Lente 1 & $38 \mathrm{~cm}$ & $\begin{array}{c}2 \text { lâminas } \\
\text { conglomeráticas, } \\
+1 \text { arenosa }+2 \\
\text { argilosas }\end{array}$ & $\begin{array}{l}0,8 \mathrm{~cm} \\
0,3 \mathrm{~cm}\end{array}$ & Lente & $\begin{array}{l}\text { Clasto- } \\
\text { suportado }\end{array}$ & Abrupto & \\
\hline & Alúvio 2 & Lente 2 & $30 \mathrm{~cm}$ & $\begin{array}{c}3 \text { camadas } \\
\text { conglomeráticas } \\
+2 \text { arenosas }+2 \\
\text { argilosas }\end{array}$ & $\begin{array}{c}\text { Grosso } 8 \\
\mathrm{~cm} \\
\text { Finos } 0,1 \mathrm{a} \\
0,5 \mathrm{~cm} \\
\end{array}$ & Lente & $\begin{array}{l}\text { Clasto- } \\
\text { suportado }\end{array}$ & Abrupto & \\
\hline & $\begin{array}{c}\text { Areia-argilosa } \\
\text { cinzenta }\end{array}$ & $\begin{array}{c}\text { Lentes } \\
\text { embutidas }\end{array}$ & Até $3 \mathrm{~cm}$ & $\begin{array}{c}\text { Grânulos e } \\
\text { seixos }\end{array}$ & & $\begin{array}{c}\text { Lentes } \\
\text { embutidas }\end{array}$ & $\begin{array}{c}\text { Matriz- } \\
\text { suportado }\end{array}$ & Abrupto & $X X X$ \\
\hline & Alúvio 1 & Lentes & Até $5 \mathrm{~cm}$ & $\begin{array}{c}\text { Areia grossa } \\
\text { bem } \\
\text { arredondada } \\
\end{array}$ & & $\begin{array}{c}\text { Lentes na } \\
\text { base da } \\
\text { unidade } \\
\end{array}$ & $\begin{array}{l}\text { Clasto- } \\
\text { suportado }\end{array}$ & & $X X$ \\
\hline & Alúvio 2 & $\begin{array}{c}\text { Lentes } \\
\text { conglomerátic } \\
\text { as da base }\end{array}$ & Até $7 \mathrm{~cm}$ & $\begin{array}{c}\text { Clastos de } 0,2 \mathrm{a} \\
1,5 \mathrm{~cm}\end{array}$ & & & $\begin{array}{c}\text { Matriz- } \\
\text { suporta-do }\end{array}$ & Abrupto & $X X X$ \\
\hline & Alúvio 2 & $\begin{array}{l}\text { Lentes do } \\
\text { topo }\end{array}$ & 5 a $10 \mathrm{~cm}$ & 0,1 a $0,3 \mathrm{~cm}$ & & & $\begin{array}{c}\text { Matriz- } \\
\text { suportado }\end{array}$ & Abrupto & $X X X X$ \\
\hline $\begin{array}{l}\text { Estrutura } \\
\text { Gradacional } \\
\text { normal }\end{array}$ & $\begin{array}{c}\text { Areia cinzenta da } \\
\text { base }\end{array}$ & $\begin{array}{l}\text { Na base da } \\
\text { unidade }\end{array}$ & $10 \mathrm{~cm}$ & $\begin{array}{c}\text { De } 0,8 \text { a } 1 \mathrm{~cm} \text { na } \\
\text { base e de } 0,1 \text { a } \\
0,2 \mathrm{~cm} \text { no topo } \\
\text { da camada }\end{array}$ & & Lentes & $\begin{array}{l}\text { Matriz- } \\
\text { suportado }\end{array}$ & Abrupto & $X X X$ \\
\hline $\begin{array}{l}\text { Estrutura } \\
\text { gradacional }\end{array}$ & Alúvio 1 & $\begin{array}{l}\text { Lentes areno- } \\
\text { sas e grânu- } \\
\text { losas }\end{array}$ & & 0,5 a $5 \mathrm{~mm}$ & $1 \mathrm{a} 2 \mathrm{~cm}$ & & $\begin{array}{l}\text { Clasto- } \\
\text { suportado }\end{array}$ & Abrupto & $X X X$ \\
\hline $\begin{array}{l}\text { Estrutura } \\
\text { gradacional }\end{array}$ & Alúvio 1 & $\begin{array}{c}\text { Lentes areno- } \\
\text { sas }\end{array}$ & & 0,5 a $2 \mathrm{~mm}$ & $1 \mathrm{a} 2 \mathrm{~cm}$ & & $\begin{array}{c}\text { Clasto- } \\
\text { suportado }\end{array}$ & Abrupto & $\mathrm{x}$ \\
\hline & Alúvio 2 & Lentes & & $\begin{array}{c}3 \mathrm{~mm} \text { no topo a } \\
1 \mathrm{~mm} \text { no topo }\end{array}$ & $5 \mathrm{~cm}$ & & $\begin{array}{c}\text { Clasto- } \\
\text { suportado }\end{array}$ & Abrupto & $X X$ \\
\hline $\begin{array}{l}\text { Estruturas de } \\
\text { deformacão }\end{array}$ & Alúvio-colúvio 1 & Baixa encosta & & $\begin{array}{c}\text { Lâminas } \\
\text { arenosas e } \\
\text { siltosas com } \\
\text { intercalação de } \\
\text { matéria orgânica } \\
\end{array}$ & & $\begin{array}{l}\text { Lâminaçõe } \\
\text { s }\end{array}$ & & & $X X X X$ \\
\hline $\begin{array}{l}\text { derormaçao de } \\
\text { pequena escala }\end{array}$ & $\begin{array}{c}\text { Horizonte } \\
\text { Organomineral } 2 \\
\end{array}$ & Baixa encosta & $+/-7 \mathrm{~cm}$ & Areno-argilosos & & $\begin{array}{c}\text { Lâminaçõe } \\
\text { s }\end{array}$ & & Gradual & $X X X X$ \\
\hline & Alúvio-colúvio 1 & $\begin{array}{l}\text { Baixa encos- } \\
\quad \text { ta }\end{array}$ & & $\begin{array}{c}\text { Contato de } \\
\text { sedimentos finos } \\
\text { lâminas } \\
\text { arenosas } \\
\end{array}$ & & $\begin{array}{l}\text { Superfície } \\
\text { de contato }\end{array}$ & & Abrupto & $X X$ \\
\hline Perturbações & Alúvio-colúvio 1 & $\begin{array}{c}\text { Horiz. } \\
\text { Organominera } \\
12\end{array}$ & & Areno-argiloso & & $\begin{array}{c}\text { Fendas de } \\
\text { dessecaçã } \\
\text { o de } 3 \mathrm{a} \\
5 \mathrm{~cm} \text { de } \\
\text { profundidad } \\
\text { e e até } 3 \\
\mathrm{~cm} \text { de } \\
\text { largura } \\
\end{array}$ & & Abrupto & $X X X X$ \\
\hline $\begin{array}{l}\text { Perturbações } \\
\text { de meso-escala }\end{array}$ & Alúvio-colúvio 1 & $\begin{array}{c}\text { Horiz. } \\
\text { Organominera } \\
12\end{array}$ & & Areno-argiloso & & $\begin{array}{l}\text { Fenda de } \\
\text { dessecaçã } \\
\text { o de } 30 \mathrm{~cm}\end{array}$ & & Abrupto & $x$ \\
\hline $\begin{array}{l}\text { Deformações } \\
\text { de macro- } \\
\text { escala }\end{array}$ & Alúvio 1, 2 & & $\begin{array}{l}\text { Até } \\
180 \mathrm{~cm}\end{array}$ & & & $\begin{array}{l}\text { Lentes e } \\
\text { camadas } \\
\text { de } \\
\text { sedimentos } \\
\text { areno- } \\
\text { argilosos }\end{array}$ & & & $X X X X$ \\
\hline $\begin{array}{l}\text { Estrutura de } \\
\text { corte e } \\
\text { preenchimento }\end{array}$ & \multicolumn{9}{|c|}{ São dois canais que ocorrem na baixa encosta, indicando trata-se de antiga voçoroca. } \\
\hline
\end{tabular}

Frequência: $X X X X$ muito alta; $X X X$ alta; $X X$ média; $X$ baixa 
Análise macroscópica e micromorfológica de estruturas sedimentares aplicada à interpretação de eventos de deposição de sedimentos em depósitos de baixa encosta no sul do segundo planalto do estado Paraná (Brasil)
Gisele Pietrobelli

Elias Machado

Eliza do Belem Tratz

Mauricio Camargo Filho Wellington Barbosa da Silva

\subsection{1 - Descrição síntese das estruturas de sedimentação identificadas}

A mais simples das estruturas intraestratais físicas é a estratificação plano-paralela (planar bedding) (SUGUIO, 1973). Trata-se de sequência de camadas superpostas paralelas ao plano de estratificação. Seus estratos são uniformes e lateralmente contínuos. Segundo Picard e High Jr (1973), a estratificação plano-paralela é particularmente comum em depósitos aluviais e ocorrem em geral nos setores terminais dos fluxos. Suguio e Bigarella (1979) sustentam que a estratificação plano-paralela é definida por sequências tabulares de lâminas ou camadas horizontais ou aproximadamente horizontais, constituídas por silte, areia ou grânulo.

A estrutura plano-paralela está presente principalmente nas unidades aluviais (Aluvio 1 e 2) e alúvio-coluvial (1) que formam lentes na baixa encosta. Portanto as lentes são formadas por diferentes laminações plano-paralelas envolvendo granulometria que varia de grânulos a silte e argila, apresentando o padrão de distribuição granulométrica das partículas clasto suportado.

É sabido que estruturas plano-paralelas são encontradas em ambientes com alta energia, fluxo de baixa viscosidade ou por correntes suficientemente fortes que impedem 0 desenvolvimento de ondas.

O padrão de organização clasto-suportado dá indícios de deposição em ambiente com corrente suficientemente forte para carrear clastos com diferentes texturas (CONYBEARE \& CROOK, 1982). Eles indicam ambiente de alta energia e ainda, segundo Selby (1994), podendo resultar de deposição por carga de fundo.

A geometria das lentes em meio às unidades, pressupõe eventos com fluxos mais vigorosos que carrearam maior número de clastos nos tamanhos grânulos e seixos. Os estratos ou lâminas internas apresentam gradação que representam as últimas fases da enxurrada ou depositadas por água pouco profunda, num fluxo difuso. Nestas lentes tem-se depósitos tipicamente aluviais que tem na estratificação sua característica mais marcante. Este tipo de estrutura pode ser encontrado em leito plano com regime de fluxo superior ou inferior a velocidade crítica de formação de marcas onduladas, ou pode ser gerado por suspensão (SUGUIO, 1980). O caráter difuso do fluxo é estimado no caso presente.

\subsection{2 - Análise micromorfológica em seção delgada 65 (Aluvial de ambiente de encosta} - Figura 3a): Camadas muito delgadas denominadas lâminas com estrutura plano-paralelas bem preservadas (Figura $3 b$ ) foram identificadas paralelamente à base da seção.

A amostra foi extraída do topo de lente rudácea do Alúvio 2 (Figura 3a). Macroscopicamente - local de amostragem abrange lâminas de material grosso (areia grossa e média) alternadas com material fino (areia muito fina e silte/argila). A análise microscópica da amostra identificou lâminas plano-paralelas bem preservadas (Figura 3b). Em função da alternância de lâminas definidas por textura de material fino e grosso na seção delgada, esta foi dividida em três zonas denominadas: terço inferior, terço médio e terço superior.

No terço inferior (Figura 3c), os materiais têm cor amarela com manchas vermelhas. A distribuição relativa $(c / f)$ é porfírica aberta à porfírica simples (partículas maiores distribuídas em matriz-S muito fina), com matriz-suportada, polimodal, pobremente selecionada $(65 \%$ esqueleto, $30 \%$ matriz, $5 \%$ microporos). A unidade é apédica. Os principais componentes do esqueleto são:

a) quartzo encontrado na fração areia fina e areia muito fina, grãos arredondados a subarredondados, lisos; b) folhelhos de cor vermelha, pouco alterados, geralmente na fração areia fina. Possuem forma alongada e plana (plácóides), subarredondados e lisos; é comum apresentarem fraturas pós-deposicionais e; c) mica muito alterada, na fração areia fina e muito fina, placoide, subarredondadas e lisas à onduladas. Esta porção da seção delgada apresenta cutans de grãos englobados por óxido de ferro hidratado iluviado, não laminados com extinção estriada. Os cutans de poros cavitários são constituídos de óxido de ferro hidratado com extinção estriada. 
Análise macroscópica e micromorfológica de estruturas sedimentares aplicada à interpretação de eventos de deposição de sedimentos em depósitos de baixa encosta no sul do segundo planalto do estado Paraná (Brasil)
Gisele Pietrobelli

Elias Machado

Eliza do Belem Tratz

Mauricio Camargo Filho Wellington Barbosa da Silva

O terço médio da seção delgada (Figura 3d), tem cor predominante amarelo claro tendendo a bege com manchas vermelhas. A amostra é apédica, com distribuição relativa ( $c / f)$ porfírica simples, gefúrica e quitônica (areia e agregados envolvidos por argila) com clastossuportados, polimodais, moderadamente selecionado (90\% esqueleto, $8 \%$ matriz e $2 \%$ poros) e sem estratificação e gradação. O esqueleto apresenta distribuição aleatória e porfírica a intertêxtica. As características dos constituintes do esqueleto são:

a) quartzo: na fração areia grossa até areia fina; subarredondados a arredondados com superfície lisa; b) folhelhos: na fração areia grossa e média, de forma tabular, arredondados e lisos; com fraturas; c) micas na fração areia média a muito fina; com forma placoide, subarredondadas e lisas a onduladas, estão muito alteradas; d) pedorrelíqueas ou agregados de solo: (Figura 3d) são amarelo claro, predominam na fração areia muito grossa e grossa, em geral são arredondados com superfície lisa ou ondulada; raramente apresentam superfície rugosa. O plasma é isótico. Os poros são microporos, ortoporos, de empilhamento ou intergranulares simples, ocorrendo, também poros cavitários e poros planares (dilatação/contração). Há predomínio de cutans de grãos englobados constituídos de óxido de ferro hidratado de cor vermelha e amarela-avermelhada. Estas feições são microlaminadas e não laminadas com extinção predominantemente estriada. Os cutans de ortoporos cavitários são compostos por óxido de ferro hidratado iluviado e podem ser microlaminados e não laminados ambos com extinção predominantemente estriada.

O terço superior da seção delgada (Figura 3e), tem cor predominante amarela clara com manchas vermelhas. Como nas demais zonas ela é apédica. A distribuição relativa $(c / f)$ é porfírica aberta a porfírica simples e localmente gefúrica com matriz suportada, polimodal, pobremente a moderadamente selecionada (65\% esqueleto, $35 \%$ matriz-S, $10 \%$ poros). A distribuição do esqueleto é predominantemente aleatória e pontualmente agrupada. Já a distribuição relativa é intertêxtica e porfírica. O esqueleto é composto por:

a) quartzos na fração areia grossa a areia muito fina; subarredondados a arredondados com superfície lisa; b) folhelhos vermelhos, na fração areia média e areia fina; bem preservados, de forma tabular, arredondados e lisos e escassos, com menos de $1 \%$ de frequência; $c$ ) micas muito alteradas, na fração areia grossa até areia fina, são abundantes (aproximadamente $25 \%$ do esqueleto), possuem forma placoide, arredondados e lisos; d) pedorrelíqueas ou agregados de solo: (Figura 3d) com características semelhantes às dos setores anteriores à exceção do tamanho, apresentando dimensões superiores a $1 \mathrm{~mm}$.

O plasma é isótico, e os poros são microporos, ortoporos, de empilhamento ou intergranulares simples, ocorrendo também poros cavitários e poros planares (dilatação/contração). Nesta porção da seção delgada há poucos cutans de grãos englobados, predominando cutans de ortoporos cavitários compostos por óxido de ferro hidratado não laminados, com extinção estriada. 
Análise macroscópica e micromorfológica de estruturas sedimentares aplicada à interpretação de eventos de deposição de sedimentos em depósitos de baixa encosta no sul do segundo planalto do estado Paraná (Brasil)
Gisele Pietrobelli

Elias Machado

Eliza do Belem Tratz

Mauricio Camargo Filho Wellington Barbosa da Silva

Figura 3 - Microfotografia da seção delgada 65. a) localização da amostra no Perfil 3 da Seção Colher; b) localização da seção delgada na fatia da amostra 65 ; c) microfotografia do terço inferior da seção delgada com plasma isótico de tendência ondúlica; d) microfotografia do terço médio da seção delgada destacando a presença de pedorrelíqueas; e) microfotografia do terço superior da seção delgada, destacando o aumento nas dimensões das pedorrelíqueas, quando comparadas com as do terço médio e inferior da seção delgada, imagens "c" e "d".

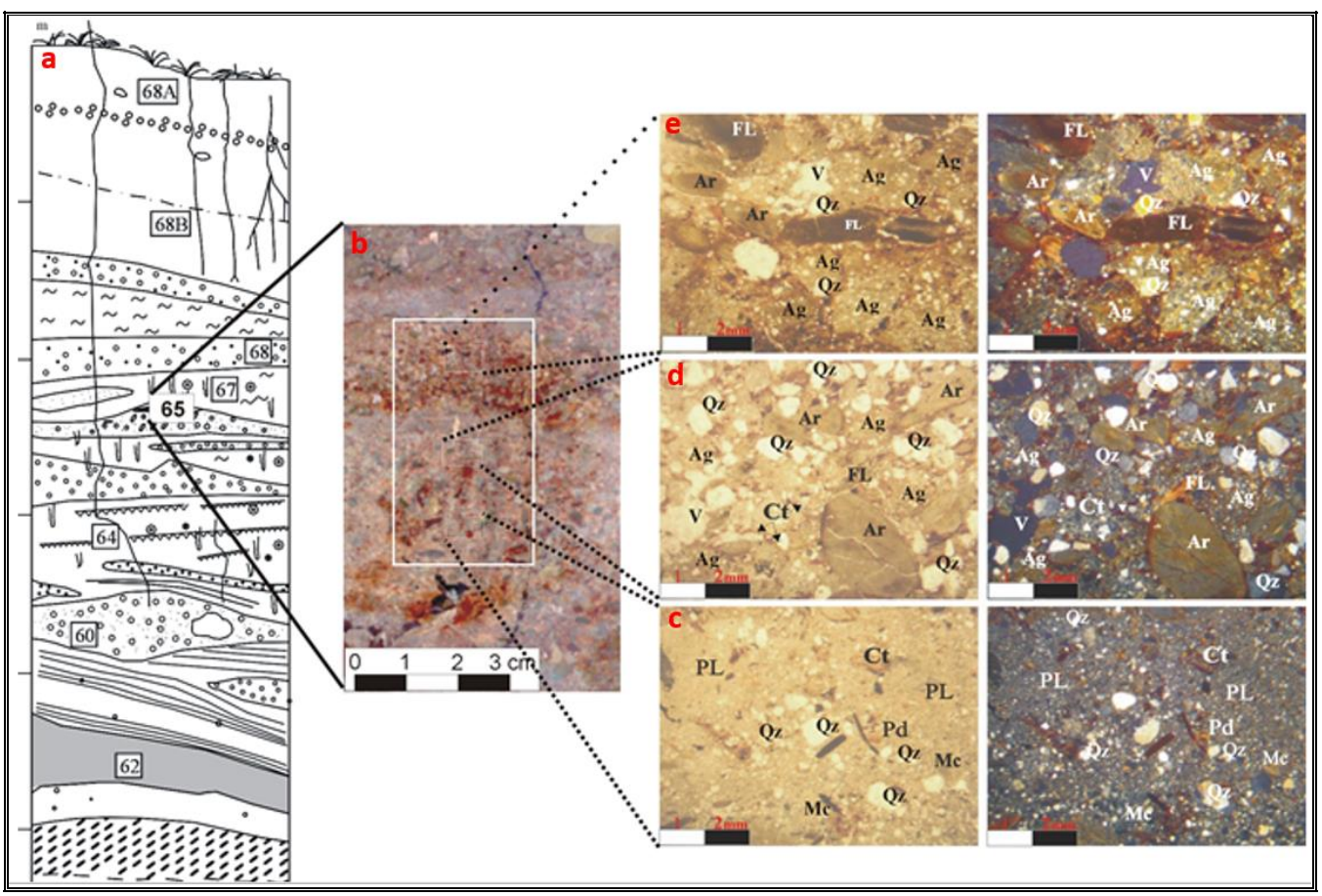

Legenda: Quartzo (Qz); mica (Mc); arenito (Ar); folhelho (FL); plasma (PL); vazios (V); cutans $(\mathrm{Ct})$; pedotúbulos $(\mathrm{Pd})$; pedorrelíqueas $(\mathrm{Ag})$; nicóis paralelos $(\mathrm{N} / /)$; nicóis cruzados (NX).

\subsection{2.a - Interpretação da seção delgada}

A estratificação com textura diversa pressupõe alternância de pulsos de energia do meio aquoso, responsável pela deposição do material, como descrito a seguir:

a) Fluxos de escoamento superficial com perda ou baixa energia com provável redução de intensidade pluviométrica depositam o material mais fino, do terço inferior da seção delgada;

b) Posteriormente, provável aumento de intensidade pluviométrica gera um pulso de maior energia ou maior volume de água, capaz de transportar material mais grosso, que se deposita formando o terço médio da seção delgada;

c) A terceira fase deposicional é marcada pela perda de competência do fluxo superficial em transportar material mais grosso. Deposita-se nova lâmina de material fino.

As estruturas sedimentares estão bem preservadas, sem alterações importantes, de origem biológica ou mesmo física. Do ponto de vista químico, foram identificados cutans de iluviação bem preservados, de cor vermelha a amarela-avermelhada, preenchendo ortoporos. A estrutura de base gefúrica (unidades grosseiras ligadas por pontes de material fino) do terço superior da seção delgada pode ser formada durante o estágio de perda de energia do fluxo ou por modificações pós-deposicionais. Aparentemente a última possibilidade é a mais provável, pois o material fino é composto por óxido de ferro hidratado com extinção estriada, quando anisotrópico. Há redução de matriz da base para o topo da amostra dando caráter aluvial mais acentuado aos sedimentos. 
Análise macroscópica e micromorfológica de estruturas sedimentares aplicada à interpretação de eventos de deposição de sedimentos em depósitos de baixa encosta no sul do segundo planalto do estado Paraná (Brasil)

A laminação plano-paralela é representada por leitos que apresentam espessura correspondente ao diâmetro de alguns grãos. Ela também pode ser determinada pela alternância de estratos ou lâminas com granulação ou conteúdo diferencial de minerais específicos, ou ambos.

\subsection{2.b - Estrutura maciça}

$\mathrm{Na}$ estratificação maciça (massive structure), os estratos apresentam pouca ou nenhuma laminação interna visível (BOGGS JUNIOR, 1992). Ela se explica presumivelmente por algum tipo fluxo de gravidade ou pela deposição muito rápida de material em suspensão (SUGUIO, 2003). Estima-se que pressões dispersivas afetem o fluxo gerando uma interação grão a grão que é mais forte que a turbulência do fluxo (NOWATZKI et al, 1984).

Essa estrutura é bastante disseminada no afloramento ocorrendo principalmente em forma de lâmina ou estrato fino e médio em todas as unidades sedimentares. Macroscopicamente predomina neste tipo de estrutura a organização das partículas clasto-suportado, que via de regra, são granulometricamente mal selecionados e em menor ocorrência tem-se o padrão de organização matriz-suportado.

5.1.3 - Análise micromorfológica em seção delgada 54b (Aluvial com estrutura maciça figura 4a). Extraída de lente rudácea em meio à unidade Alúvio-colúvio 1. A cor predominante do material é amarela clara, com manchas marrons. A amostra é apédica, com distribuição relativa (c/f) mônica e enáulica. Os clastos são suportados, polimodais, moderadamente selecionados ( $70 \%$ esqueleto, $10 \%$ matriz e $20 \%$ poros). O esqueleto apresenta distribuição de base aleatória, pontualmente agrupada e distribuição relativa granular a intertêxtica. $O$ esqueleto é constituído basicamente por grânulos de arenito, folhelho e pedorrelíqueas, e na fração areia por mica e quartzo. As principais características do esqueleto são:

a) quartzo presente em todas as frações de areia, são subarredondados e arredondados com superfícies lisas;

b) folhelhos são vermelho brunado, na fração grânulo e areia muito grossa e grossa com forma tabular, arredondados e lisos, geralmente muito alterados;

c) arenito relativamente bem preservados, arredondados e subarredondados, com superfícies lisas e/ou onduladas; na fração grânulo e areia muito grossa; via de regra, aproximadamente $60 \%$ destes clastos possuem hipocutans e;

d) pedorrelíqueas bem preservadas a moderadamente preservadas, com cores amarela clara e vermelha amarronada; predominantemente na fração grânulo e em menor quantidade na fração areia muito grossa e grossa; via de regra são bem individualizadas, arredondadas com superfície lisa ou ondulada.

A estrutura plásmica, quando identificada, é predominantemente isótica. Os poros são ortoporos de empilhamento ou intergranulares simples, além de poros cavitários (Figura 4). 
Análise macroscópica e micromorfológica de estruturas sedimentares aplicada à interpretação de eventos de deposição de sedimentos em depósitos de baixa encosta no sul do segundo planalto do estado Paraná (Brasil)
Gisele Pietrobelli

Elias Machado

Eliza do Belem Tratz

Mauricio Camargo Filho Wellington Barbosa da Silva

Figura 4 - a) Localização da amostra no Perfil 2 da Seção Colher; b) localização da amostra na fatia da amostra 54b; c) microfotografia da seção delgada 54b com destaque para a elevada participação das pedorrelíqueas e para os ortoporos de empilhamento e cavidades.

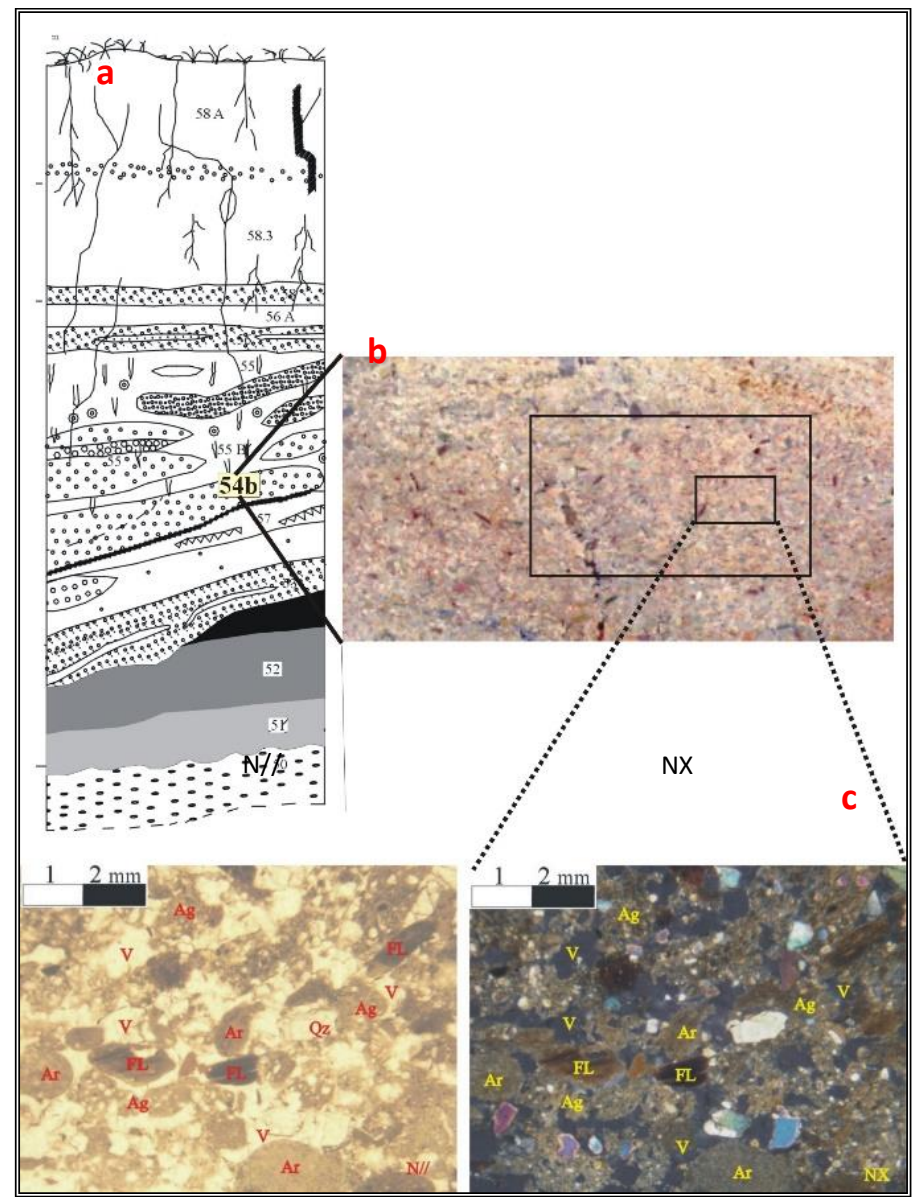

Nota: Quartzo $(\mathrm{Qz})$; arenito $(\mathrm{Ar})$; folhelho $(\mathrm{FL})$; agregados de solo $(\mathrm{Ag})$; vazios $(\mathrm{V})$; nicóis paralelos (N//); nicóis cruzados (NX).

Cutans ocorrem somente na forma de grãos livres, e são constituídos de óxido de ferro hidratado de cor vermelha e amarela avermelhada. Geralmente não apresentam microlaminações e têm extinção difusa.

\subsection{3.a - Interpretação da seção delgada}

A presença de ortoporos de empilhamento simples e cavitários sem sinais de eluviação, bem como o elevado número de pedorrelíqueas, cujas características internas não correspondem àquelas do meio em que se encontram, assim como a distribuição de clastos suportados polimodais, indicam tratar-se de depósito aluvial, submetido a processos intempéricos pósdeposicionais, como indica a presença de micas muito alteradas. Não foram identificadas feições relacionadas à atividade biológica. A compactação apresentada por algumas pedorrelíqueas tem sua origem no aumento de pressão pós-deposicional. 
Análise macroscópica e micromorfológica de estruturas sedimentares aplicada à interpretação de eventos de deposição de sedimentos em depósitos de baixa encosta no sul do segundo planalto do estado Paraná (Brasil)
Gisele Pietrobelli

Elias Machado

Eliza do Belem Tratz

Mauricio Camargo Filho Wellington Barbosa da Silva

\subsection{4 -Análise micromorfológica de seção delgada 80.2 retirada do topo do Alúvio 2 (Aluvial}

de encosta moderadamente pedogenizada - Figura 5a).

Há relativa homogeneidade na distribuição do plasma e do esqueleto, com feições pedológicas restritas a cutans de grãos e poucos preenchimentos, além de alguns nódulos puros (Figura 5 c).

Figura 5 - Microfotografias da seção delgada 80.2; a) localização da amostra no Perfil 1 da seção Colher; b) localização da seção delgada na fatia da amostra 80.2; c) distribuição relativa porfírica aberta e de base aleatória (5 magnificações) (note presença de nódulos milimétricos nesta porção da seção delgada); d) detalhe do plasma esquel-massépico:

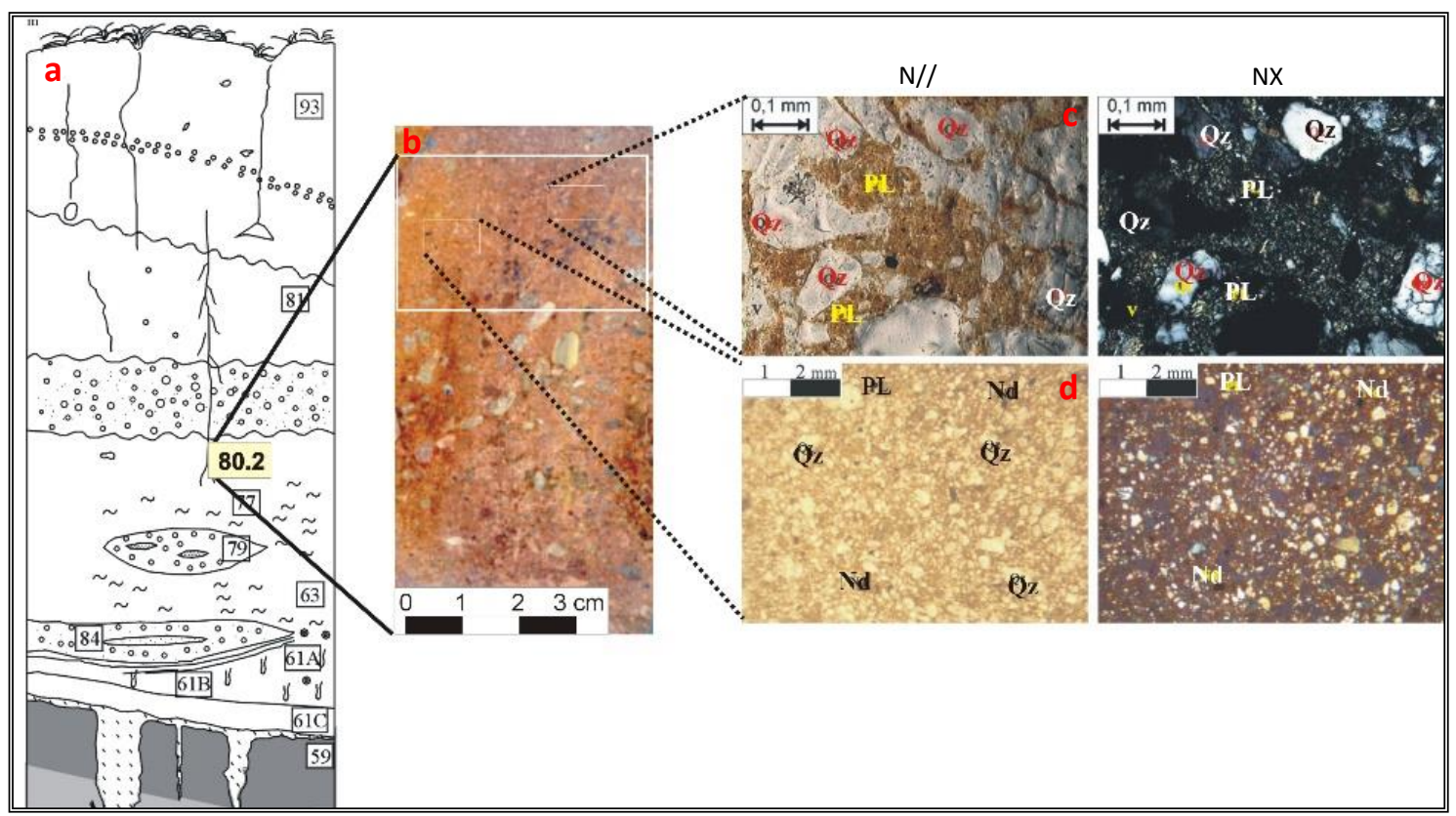

Nota: Quartzo (Qz); plasma (PL); vazios (V); nódulos puros (Nd); nicóis paralelos (N//); nicóis cruzados (NX).

A cor do material em seção delgada é amarelo-clara com manchas vermelhas (5\%). A distribuição relativa (c/f) é predominantemente porfírica simples (partículas maiores distribuídas em matriz-S muito fina), matriz suportada, polimodal, moderadamente selecionada ( $50 \%$ areia, $30 \%$ matriz, $20 \%$ poros) sem estratificação e gradação, com pedalidade moderadamente desenvolvida, do tipo granular a blocos subangulares. $O$ esqueleto apresenta distribuição de base aleatória (figura $5 \mathrm{c}$ ), pontualmente agrupada e bandeada. $\mathrm{O}$ esqueleto é formado por poucos fragmentos de arenito na fração areia muito grossa, arredondados com superfícies lisas e quartzo na fração areia media, fina e muito fina, subarredondados e arredondados com superfícies lisas.

O plasma é esquel-massépico e insépico (figura $5 \mathrm{~d}$ ). A presença de cutans típicos é rara, sendo mais comum cutans de grãos englobados e preenchimentos (infilling). Em ambos os casos 0 material é composto por óxido de ferro hidratado, provavelmente quelatizado com matéria orgânica (húmus). As cores desses cutans são amarela-avermelhada e vermelha amarronada. Há poucos pedotúbulos.

\subsection{4.a - Interpretação da seção delgada}

Seção delgada de material moderadamente pedogenizada, sem importantes feições de bioturbação nem evidências claras de iluviação ou transferência de material atual. A presença de plasma esquel-massépico, sugere sítio submetido à pressão e tensão por umedecimento e 
Análise macroscópica e micromorfológica de estruturas sedimentares aplicada à interpretação de eventos de deposição de sedimentos em depósitos de baixa encosta no sul do segundo planalto do estado Paraná (Brasil)
Gisele Pietrobelli

Elias Machado

Eliza do Belem Tratz

Mauricio Camargo Filho Wellington Barbosa da Silva

ressecamento. De acordo com Brewer (1972), a origem de plasma massépico pode estar associada a estes processos, em especial à pressão produzida pelo intumescimento do solo, 0 qual poderia gerar fluxos plásticos que poderiam obliterar estruturas pré-existentes, que porventura tenha existido no solo.

\subsection{4.b - Estrutura gradacional}

Gradação ou estrutura gradacional (graded bedding) pode ser produzida por sedimentação de nuvens em suspensão, por deposição nas últimas fases de fortes enxurradas (BOGGS JR, 1992) ou por águas muito rasas, formando unidades pouco espessas (SUGUIO, 2003). O arranjo dos sedimentos nas lentes constituídas por material grosso é clasto-suportado dando indícios de deposição em ambiente onde a corrente é suficientemente forte para carrear clastos de maior granulação. Segundo Selby (1994), eles podem resultar também de deposição por carga de fundo. Nestes estratos as unidades sedimentares são caracterizadas por gradação no tamanho do grão, de grosso a fino, e da base ao topo da unidade (PETTIJOHN, 1963; CONYBEARE \& CROOK, 1982). Conybeare e Crook (1982) explicam que as estruturas gradacionais ocorrem geralmente em sequências de diversas unidades, com contatos abruptos indicando lavagem na base de cada unidade. Boggs Junior (1992) cita ainda a gradação inversa quando as partículas mais finas situam-se na base e as mais grossas no topo da estrutura. Gradação de ambiente de águas rasas geralmente compõem unidades delgadas de poucos milímetros a 1 a $2 \mathrm{~cm}$ e raramente fazem sequências de maiores que $20 \mathrm{~cm}$.

A estrutura gradacional ocorre em três unidades de sedimentação, porém de forma muito restrita às lentes conglomeráticas e granulosas com padrão de distribuição das partículas clastosuportado. As gradações são observadas em sedimentos de água pouco profundas e em geral são isolados e esporádicos.

No topo da unidade Areia-argilosa Cinzenta, ocorre uma lente de clastos com gradação normal em organização matriz-suportado. No Alúvio 1, a estrutura gradacional normal está presente nas lentes com clastos de areia grossa e grânulos. Nas lentes com fragmentos menores, a gradação é inversa, embora seja pouco perceptível. No Alúvio 2, a gradação normal está presente na penúltima lente da unidade.

Em depósitos aluviais a estratificação gradacional é, segundo Picard e High Jr (1973), uma estrutura bem difundida. Em geral as maiores ocorrências se dão no interior de unidades de sedimentação, em que os sedimentos da porção inferior da sedimentação são mais grossos que aqueles da porção superior. Em depósitos aluviais ela é resultante da redução da velocidade do fluxo que é acompanhada por mudanças na forma do leito que são indicativas de decréscimo progressivo na velocidade do fluxo. Os primeiros depósitos são clastos relativamente grossos transportados por correntes vigorosas e com a redução da velocidade da corrente diminui também o tamanho da carga de fundo que se torna progressivamente menor (PICARD \& HIGH $J R, 1973)$.

\subsection{4.c Estruturas de deformação (soft-sediment deformation structures)}

Estruturas de deformação ou estruturas reológicas são estruturas que resultam da deformação de sedimentos coesos ou variações reológicas graças às forças diferentes daquelas influenciadas diretamente por correntes e organismos (CONYBEARE e CROOK, 1982; NOWATZKI et al., 1984). As classes reológicas são definidas de acordo com o grau de liberdade da partícula no sedimento no período em que a estrutura é produzida.

O primeiro estado de sedimentos é o reológico sólido. Neste caso os sedimentos são tão resistentes que as deformações ocorrem por fraturamento. $O$ segundo estado é o chamado estado reológico quase-sólido, em que a resistência do sedimento não é tão grande, mas a deformação ainda se dá por fratura. No terceiro estado, reológico hidroplástico, o sedimento apresenta pouca coesão, as partículas individuais podem mover-se, e a massa pode mudar de forma. No quarto estado reológico, em que o sedimento comporta-se como quase-líquido, há coesão muito fraca entre as partículas, que apresentam liberdade considerável de movimento dentro do sedimento que está sendo deformado. As partículas passam a ocupar

$\begin{array}{llllll}\text { Caminhos de Geografia } & \text { Uberlândia } & \text { v. 20, n. } 72 & \text { Dezembro/2019 } & \text { p. 537-559 } & \text { Página } 551\end{array}$


Análise macroscópica e micromorfológica de estruturas sedimentares aplicada à interpretação de eventos de deposição de sedimentos em depósitos de baixa encosta no sul do segundo planalto do estado Paraná (Brasil)

novas posições dentro do corpo sedimentar. Por fim, no quinto estado, reológico líquido, há uma completa perda de coesão, as partículas individuais são livres e hábeis para mover-se dentro e fora do corpo de sedimento. Neste caso os sedimentos não exibem estrutura deformacional, mas podem exibir uma variedade de estruturas hidrodinâmicas (CONYBEARE \& CROOK, 1982).

No processo de deformações geradas por expulsão de água, elas originam-se quando sedimentos hidroplásticos, liquefeitos ou fluidizados são mobilizados ou introduzidos em camadas adjacentes. Pode ser concordante, quando a intrusão é hidroplástica; tipicamente discordante quando a intrusão fluidizada e, concordante ou discordante quando a intrusão é liquefeita (NOWATZKI et al. 1984).

Os dobramentos são reconhecidos, segundo Collinson e Thompson (1984) e Selby (1994), como estruturas que ocorrem quando sedimentos inconsolidados repousam na encosta e tornam-se instáveis, possivelmente devido à elevada poropressão em uma camada particular de sedimentos. Unidades de sedimentos dobrados atribuídos a deslizamento geralmente ocorrem em sequências interestratificada, contendo uma substancial proporção de sedimentos finos. Geralmente as dobras são circundadas por sedimentos não perturbados (COLLINSON e THOMPSON, 1984).

Em sedimentos argilosos, o escape de água acarreta em diminuição do volume dos sedimentos. Quando a porosidade é reduzida em mais da metade as partículas entram em contato umas com as outras aparecendo verdadeira coesão entre elas. O processo predominante desta fase é a deformação mecânica (CLEMENT e PÉRES-ARLUCEA, 1993). Esses autores afirmam que as deformações sindeposicionais (como dobras convolutas, dobras sinsedimentares, estrutura acanalada deformada) são interpretadas como sendo de origem de escape de água devido à rápida deposição durante as enxurradas, produzindo alta poropressão e instabilidade, seguida por migração de água para zona de baixa pressão.

\section{a) Estruturas em escala de afloramento e de mão}

Entre as estruturas de sedimentação de caráter pós-deposicional; incluem-se estruturas de deformação plástica ou de rompimento de escala milimétrica a métrica no âmbito das unidades sedimentares. Neste estudo, sob a perspectiva das propriedades hidroplásticas dos materiais, foram registrados falhamentos, dobramentos e escape de água. Ainda se incluem gretas de contração como estrutura pós-deposicional que perturbou os sedimentos. As estruturas de micro e meso-escala afetaram somente o Alúvio-colúvio 1, predominantemente o Horizonte Organomineral 2 ou a interface entre este e os sedimentos areno-argilosos sobrejacentes. As estruturas pós-deposicionais de macro-escala estão marcadas por dobras e inflexões de lentes das unidades sedimentares da base da seção (Alúvio-colúvio 1 e 2, Alúvio 1 e 2, em especial o Paleo-horizonte organomineral 2) próximas e em direção à estrutura de corte e preenchimento da Seção Colher.

As estruturas de deformação que ocorrem nos sedimentos de encosta apresentam dimensões que variam de poucos milímetros a dois ou três metros. Inicialmente serão apresentadas estruturas de microescala (da ordem de milímetros até $2 \mathrm{~cm}$ ), que estão restritas às unidades sedimentares.

No Alúvio-colúvio 1, em direção à baixa encosta, há lâminas argilo-arenosas intercaladas com lâminas argilosas enriquecidas com matéria orgânica, que apresentam deformações e estruturas de escape de água (Figura 6). No presente caso, os sedimentos de uma lâmina aparecem introduzidos nas lâminas adjacentes, sugerindo a presença de intrusões de sedimentos fluidizados.

Ainda no Alúvio-colúvio 1, na base onde se dá o contato entre os sedimentos argilosos com as lentes de sedimentos grossos, ocorre falha com rejeito de $1 \mathrm{~cm}$ (Figura 7). No presente caso, o estado reológico do sedimento é quase-sólido para gerar deformação por fratura. 
Análise macroscópica e micromorfológica de estruturas sedimentares aplicada à interpretação de eventos de deposição de sedimentos em depósitos de baixa encosta no sul do segundo planalto do estado Paraná (Brasil)
Gisele Pietrobelli

Elias Machado

Eliza do Belem Tratz

Mauricio Camargo Filho Wellington Barbosa da Silva

Figura 6 - Marcas de estrutura fluidizada em sequência de lâminas em sedimentos finos do Alúvio-colúvio 1 (Am 92).

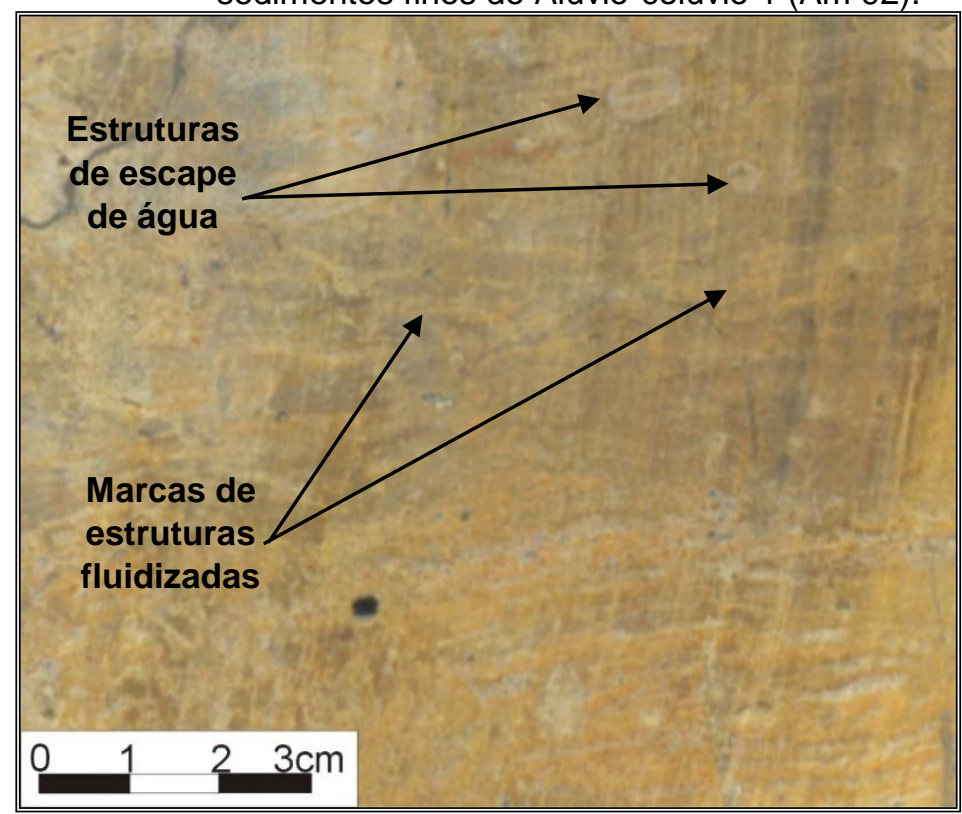

Figura 7 - Falha de micro-escala em superfície de contato de sedimentos grossos (a) e finos (b) do Alúvio-colúvio 1 (Am 82).

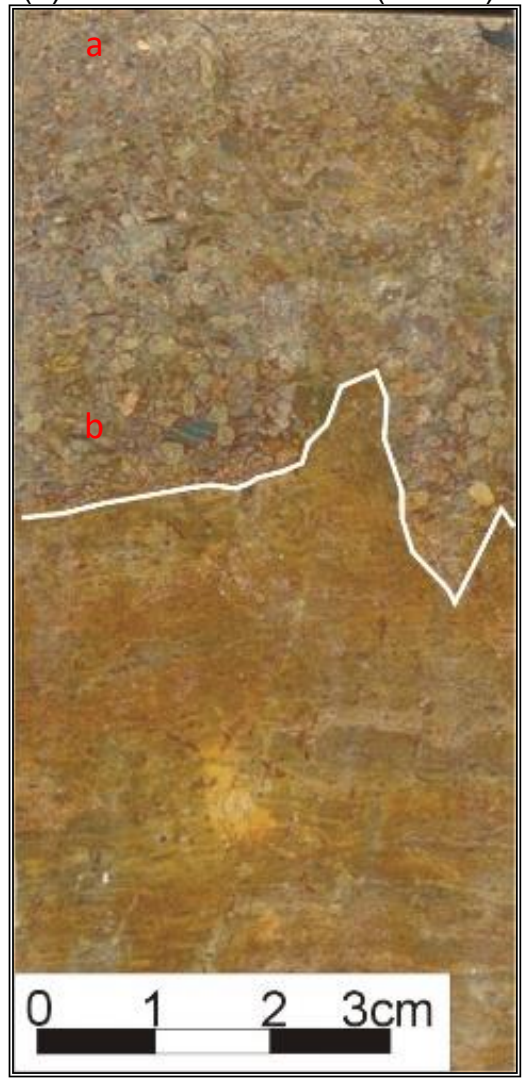


Análise macroscópica e micromorfológica de estruturas sedimentares aplicada à interpretação de eventos de deposição de sedimentos em depósitos de baixa encosta no sul do segundo planalto do estado Paraná (Brasil)

As perturbações de sedimentos em meso-escala envolvem estruturas ou feições com dimensão de centímetros a decímetros. Entre as perturbações de meso-escala, têm-se fendas de dessecação que ocorrem nos Paleo-horizontes organominerais 1 e 2. A Figura 8 representa essas perturbações.

No primeiro caso tem-se fendas de dessecação de 2 a $3 \mathrm{~cm}$ de profundidade e menos de $0,5 \mathrm{~cm}$ de largura preenchidas por areia fina e média muito bem selecionada. No Alúvio-colúvio 1 as fendas têm $23 \mathrm{~cm}$ de profundidade e foram preenchidas por areia fina e média, muito bem selecionada e bem lavada.

Além de preencher fendas, estas areias formaram uma camada de até $18 \mathrm{~cm}$ de espessura que capeiam este paleo-horizonte. O contato dessas areias com os sedimentos areno-argiloso pretos do Paleo-horizonte Organomineral 2 é gradual, por vezes indefinido, e não raro estão perturbados.

A Figura 8 apresenta as fendas de dessecação nesse horizonte. Ainda no Paleo-horizonte Organomineral 2, em direção à baixa encosta, as areias que capearam esse horizonte geraram lâminas recurvadas de material arenoso e organomineral

Figura 8 - a) Zona de contato entre Horizonte Organomineral 2 e as areias que penetraram nas fendas de dessecação (Am 59). Em b) fendas de dessecação preenchidas por areia no Horizonte Orga-nomineral 1, com destaque para o nível de oxidação.

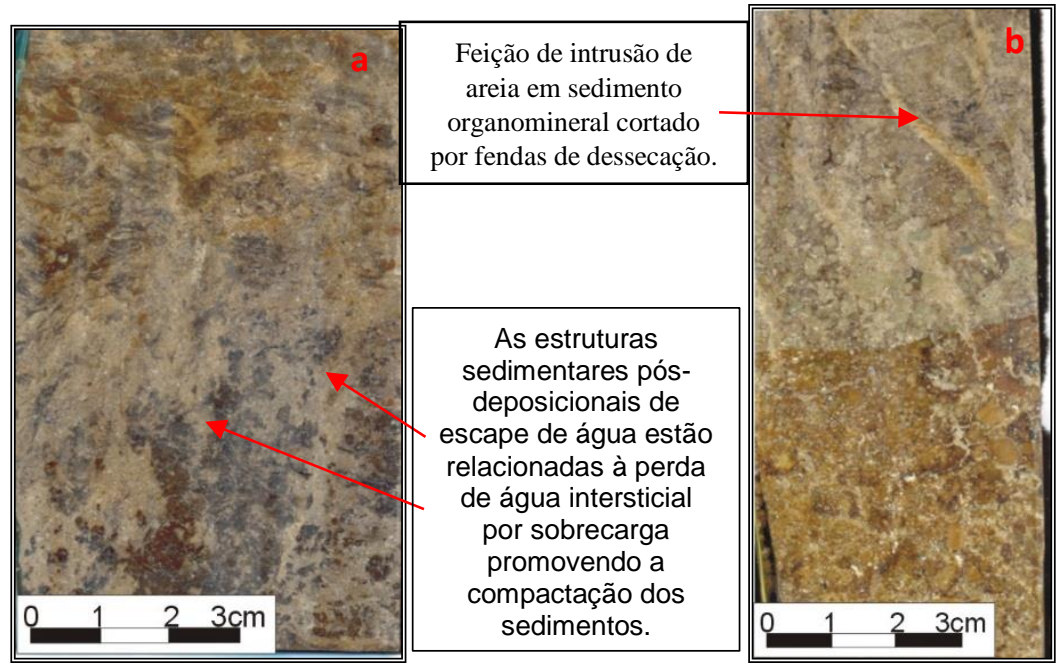

Esta deformação de maior tamanho envolveu grande parte de todo o pacote sedimentar na encosta. As deformações estão visíveis abaixo das últimas lentes conglomeráticas do Alúvio 2 , no Alúvio-colúvio 1 e na Areia-argilosa Cinzenta. As lentes conglomeráticas, o horizonte organomineral 2 e as marcas paralelas de oxidação dos sedimentos mergulham de 15 a $20^{\circ} \mathrm{em}$ sentido contrário à declividade da encosta. A deformação das unidades de sedimentos inferiores pode ser vista na Figura 9. Essa perturbação de maior magnitude nos sedimentos é atribuída à elevação de poropressão devido à rápida sedimentação que preencheu o paleo-canal. 
Análise macroscópica e micromorfológica de estruturas sedimentares aplicada à interpretação de eventos de deposição de sedimentos em depósitos de baixa encosta no sul do segundo planalto do estado Paraná (Brasil)

Figura 9 - Deformação de sedimentos junto ao canal da Seção Colher: neste setor o abatimento das unidades Areia-argilosa Cinzenta e Horizonte Organomineral 2 em sentido reverso à declividade da encosta. A seta indica o páleo-horizonte e unidades superiores que sofreram deformação.

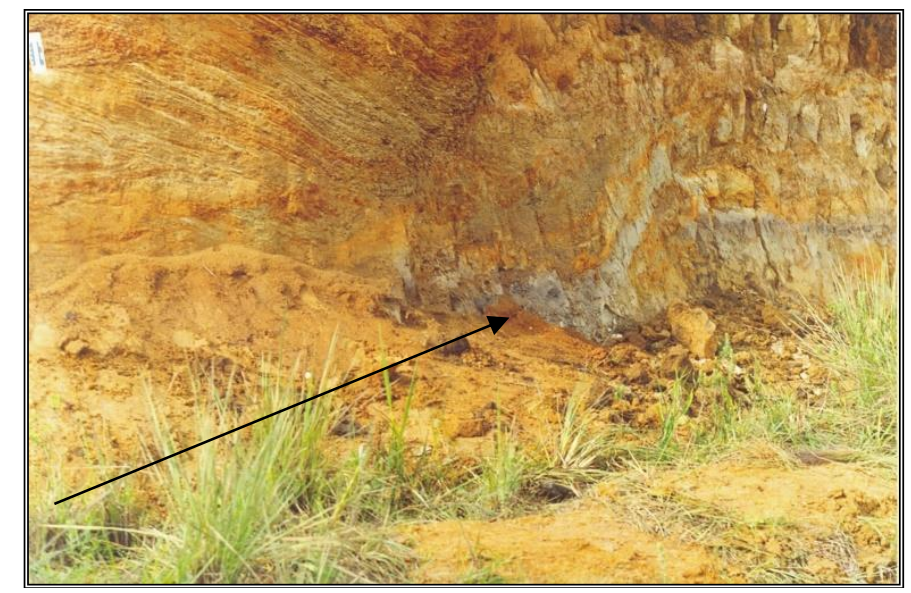

\subsection{4d -Análise micromorfológica de seção delgada da amostra 59 a (Horizonte Organomineral 2)}

O Horizonte Organomineral 2 (Figura 10) constitui uma unidade que se estende por todo o perfil, destaca-se pela cor escura e pela plasticidade quando úmido, com fendas de dessecação preenchidas por areia fina e muito fina. Sofreu deformações importantes junto à estrutura de preenchimento de canal. Ele foi datado em 22.050 (+620/-580) anos AP (CAMARGO, 2005).

A descrição e análise micromorfológica da seção delgada (Figura 10b) demonstram que esse horizonte é rico em feições pedológicas como cutans, preenchimentos (infillings), nódulos e pápulas. A cor do material, em seção delgada é bruno com manchas $(5 \%$ a $10 \%$ visível em seção delgada) vermelho amarelado e vermelho brunado. A distribuição relativa (c/f) é porfírica simples (partículas maiores distribuídas em matriz-s fina), matriz suportada, polimodal, pobremente selecionada, sem estratificação e gradação. A pedalidade é moderada a fortemente desenvolvida, do tipo granular. O esqueleto possui distribuição de base aleatória, pontualmente agrupada e/ou concêntrica. A distribuição relativa (indivíduos semelhantes em relação a indivíduos diferentes) é predominantemente porfírica, podendo apresentar porções intertêxtica. O esqueleto é formado predominantemente por quartzo, na fração areia muito grossa a fração areia muito fina. A fração grânulo corresponde a aproximadamente $1 \%$ do esqueleto. Os principais componentes do esqueleto e suas características são: quartzo $(\mathrm{Qz})$ : encontrado em todas as frações de areia, bem preservados, são predominantemente arredondados e subarredondados, com superfície lisa e arenito: encontrado na fração grânulo e areia muito grossa, em geral é bem preservado, subanguloso, liso ou ondulado.

A estrutura plásmica sépica é massépica, esquelsépica e esquel-massépica. A matéria orgânica (húmus) apresenta o plasma é isótico (figura 10c, NX). Os poros são predominantemente ortoporos, de empilhamento simples, além de fissuras planares (ressecamento e umedecimento) e canais e câmaras. Cutans são relativamente comuns e com diâmetros que não ultrapassam 1 $\mathrm{mm}$. Cutans ortocavitários, de canais e câmaras são os mais comuns. Via de regra são amareloavermelhados, com extinção difusa e ausente. Cutans de fissuras planares e ortocavitários possuem extinção difusa. O material é composto por óxido de ferro hidratado não laminado. Aproximadamente $20 \%$ dos cutans apresentam micro-fissuras planares resultantes de processos de umedecimento e ressecamento. 
Análise macroscópica e micromorfológica de estruturas sedimentares aplicada à interpretação de eventos de deposição de sedimentos em depósitos de baixa encosta no sul do segundo planalto do estado Paraná (Brasil) Wellington Barbosa da Silva

Figura 10 - a) Localização da amostra no Perfil 1 ; b) localização da seção delgada na fatia da amostra 59a; c) microfotografia da seção delgada 59a (note a variação na estrutura plásmica da amostra).

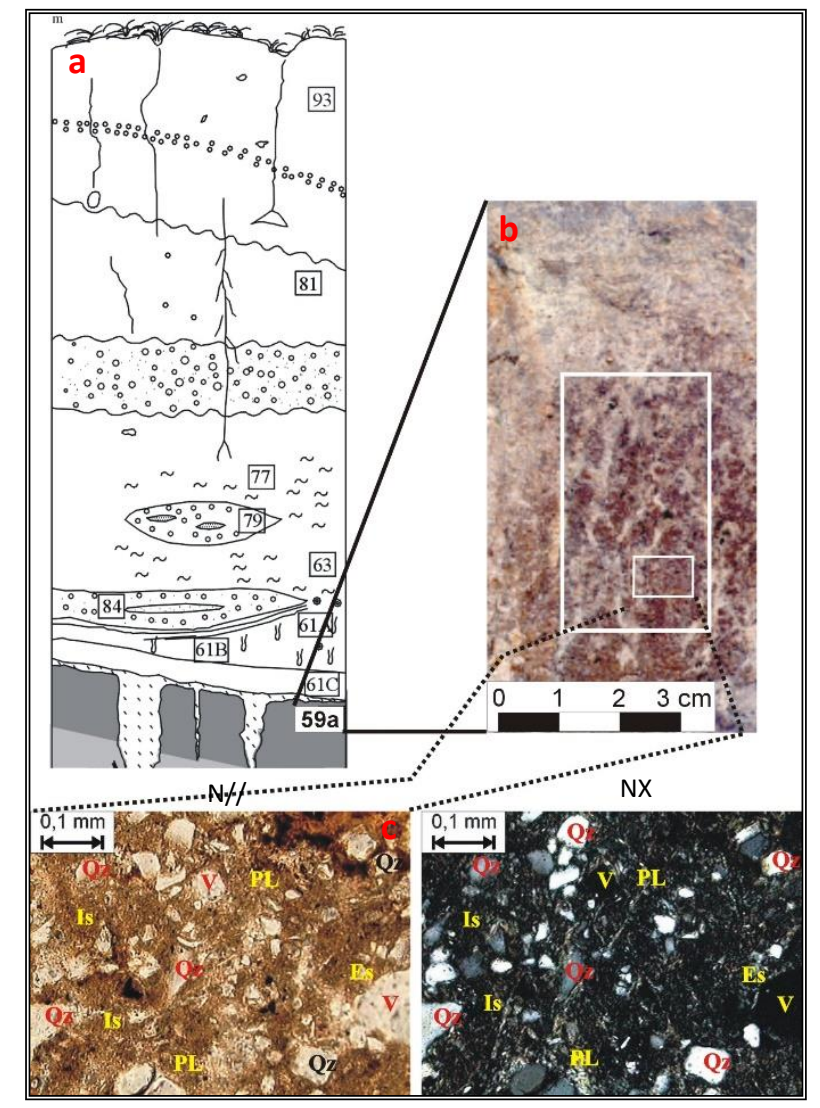

Nota: Estrutura plásmica massépica e esquel-massépica (PL); esquelsépica (Es); plasma isótico (Is); vazios (V); quartzo (Qz); nicóis paralelos (N//); nicóis cruzados (NX).

Na seção delgada foram identificadas duas fendas de dessecação, originadas por ressecamento deste horizonte organomineral. Estas fendas, em seção delgada delgada, têm até $12 \mathrm{~mm}$ de profundidade por até $2 \mathrm{~mm}$ de largura. As paredes dessas fendas apresentam larguras variadas ao longo de sua extensão e terminação aguda, são concordantes e se encaixam perfeitamente, sendo distinguíveis do restante do material da seção delgada. São preenchidas por esqueleto de quartzo na fração areia fina e muito fina, arredondados, subarredondados e lisos. A distribuição de base é aleatória e a relação indivíduos semelhantes e indivíduos diferentes é granular. Os poros são de empilhamento simples com cutans de grãos livres.

\section{a) Interpretação da seção delgada}

A descrição da seção delgada e sua interpretação, em conjunto com dados de campo permitem compreender que a evolução a unidade se deu da maneira:

1) A presença de plasma massépico e esquel-massépico indica sítio submetido à pressão por umedecimento capaz de torná-lo relativamente plástico. A cor bruno da unidade, bem como a presença, mesmo que pontual, de plasma isótico deve-se à presença de húmus. A ausência de biotúbulos maiores que $2 \mathrm{~mm}$ indica cobertura de gramíneas; 2) Este horizonte organomineral passou por intenso período de ressecamento, o que é evidenciado por paleofendas de dessecação macro e microscópicas que não formam Gilgai, nem indicam origem relacionada a sucessivos processos de ressecamento e umedecimento (dilatação e contração), típico de 
Análise macroscópica e micromorfológica de estruturas sedimentares aplicada à interpretação de eventos de deposição de sedimentos em depósitos de baixa encosta no sul do segundo planalto do estado Paraná (Brasil)

ambientes sujeitos a grandes contrastes climáticos (secas alternadas por períodos úmidos). Considera-se, portanto, que elas estiveram submetidas apenas a um período seco e sofreram rápida deposição aluvial de areias que preencheram as fendas, antecedida apenas decapitação do horizonte A.

\section{CONSIDERAÇÕES FINAIS}

A análise macroscópica e micromorfológica dos paleo-horizontes organominerais e das estruturas sedimentares ajudaram a interpretar os fluxos que as geraram, bem como as condições às quais o ambiente esteve sujeito.

Estrutura plano-paralela está associada a fluxos de alta energia e baixa viscosidade e flutuações desta energia se manifesta na estratificação por granulação. A baixa viscosidade reflete a ausência ou redução dos constituintes de granulação mais fina como silte e argila. A estrutura maciça, que é bem disseminada no perfil está relacionada com fluxo mais vigorosos com rápido decréscimo da energia, ocasionando rápida deposição, o que se estima que, localmente, esteja relacionado à rupturas no declive da encosta. Ao apresentar a organização dos constituintes do tipo clasto-suportado estima-se tratar de fluxo bipartido, no qual a base é constituída por tapetes de tração.

Nas lentes e unidades com estrutura maciça a organização dos constituintes é matriz-suportado de granulação mais grossa e petrorrelíqueas, que estão relacionadas também com fluxos mais vigorosos, porém mais densos, que transportaram e depositaram esses materiais heterométricos.

A estrutura gradacional teria sua gênese relacionada a correntes fortes o suficiente para transportar clastos de maior granulação ou por deposição de carga de fundo. Ao apresentar organização do tipo matriz-suportado prevê-se fluxos mais densos.

Entre as estruturas de deformação prevalecem as de comportamento hidroplástico a quaselíquido uma vez que a perda de coesão entre as partículas varia desde a deformação até a fluidização. O desenvolvimento de estruturas de deformação é favorecido pela presença de água e sedimentos com teor de argila suficientes para dar plasticidade aos corpos. As gretas de contração foram formadas a partir de um único período de ressecamento evidenciado por suas paredes e não encapsulamento das áreas que as preencheram.

Assim, conclui-se que predominaram na geração das estruturas fluxos mais vigorosos com baixa densidade. Dois períodos distintos com intensa pedogênese dominaram sobre a encosta gerando os páleo-horizontes organominerais, nas demais situações os processos deposicionais foram predominantes sobre os processos pedogenéticos uma vez que as estruturas sedimentares encontram-se bem preservadas permitindo o presente estudo.

\section{REFERÊNCIAS}

ALLEN, J. R .L. On bed forms and palaeocurrents. Sedimentology, v. 6, p. 153-190, 1966. https://doi.org/10.1111/j.1365-3091.1966.tb01576.x

ALLEN, J. R. L. Sedimentary Structures: their character and physical basis. Elsevier, Development in sediment, n. 30, Amsterdam, v.1 e 2, 1984. 592p.

BATES, R. L.; JACKSON, J. A. (Eds). Glossary of Geology. 4a ed. Virginia: Julia A. Jackson Ed., 1997. 769p.

BIGARELLA, J. J.; MOUSINHO, M. R. Significado paleogeográfico e paleoclimático dos depósitos rudáceos. Boletim Paranaense de Geografia. n. 16/17, , p. 7-16, jul. 1966

BOGGS JR, San. Petrology of sedimentary rocks. New York: Macmillan Publishing Company, 1992. 707p. 
Análise macroscópica e micromorfológica de estruturas sedimentares aplicada à interpretação de eventos de deposição de sedimentos em depósitos de baixa encosta no sul do segundo planalto do estado Paraná (Brasil)
Gisele Pietrobelli

Elias Machado

Eliza do Belem Tratz

Mauricio Camargo Filho Wellington Barbosa da Silva

BREWER, R. The basis of interpretation of soil micromorphological data. Geoderma, v.8, p. 8194, 1972. https://doi.org/10.1016/0016-7061(72)90037-7

BULLOCK, P.; FEDOROFF, N., JONGERIUS, A.; STOOPS, G.; TURSINA, T. Handbook for Soil Thin Section Description. Albrighton: Waine Research Publications, 1985. 152p.

CAMARGO, G. Processo de erosão no Centro e Sul do Segundo Planalto Paranaense: evolução de encosta e influência da erosão subterrânea na expansão de voçorocas. 1998. 210p. Dissertação (Mestrado em Geografia) - Universidade Federal de Santa Catarina, Florianópolis.

CAMARGO, G. Significado Paleoambiental de depósitos de encosta e de preenchimento de canal no Município de Lapa (PR) no Sul do Segundo Planalto Paranaense. 2005. 302p. Tese (Doutorado em Geografia) - Universidade Federal de Santa. Catarina. Florianópolis.

CASTRO, S. S. Micromorfologia de solos: pequeno guia para descrição de lâminas delgadas. Apostila. IPT/CAPESXCOFECUB/DG-USP, 1989.

CLEMENTE, P.; PÉREZ-ARLUCEA, M. Depositional architecture of the Cuerda del Pozo Formation, Lower Cretaceos of the extensional Cameros Basin, North-Central Spain. Journal Sedim. Petrology, Cambridge, v. 63, n.3, p. 437-452, may. 1993. https://doi.org/10.1306/D4267B1D-2B26-11D7-8648000102C1865D

COLLINSON, J. D.; THOMPSON, D.B. Sedimentary Structures. 2. ed. Hemel Hempstead: George Allen\&Unwin, 1984. 194p.

CONYBEARE, C. E .B.;CROOK, K. A. W. Manual of Sedimentary Structures 2. ed. Bureau of Mineral Resources Geology and Geophysics. Bulletin 102, Camberra Watson Ferguson and Co., 1982. 327p.

EMPRESA BRASILEIRA DE PESQUISA AGROPECUÁRIA - EMBRAPA. Serviço Nacional de Levantamento e Conservação de Solos. Manual de Métodos de Análise de Solos, 1979.

FERREIRA, G. dos S. S. ; OLIVEIRA, M. A. T. . Aplicação da micromorfologia de solos ao estudo de sedimentos alúvio-coluviais em cabeceiras de vale. Pesquisas em Geociências (UFRGS) , v. 33, p. 3-18, 2006. https://doi.org/10.22456/1807-9806.19509

FITZPATRICK, E. A. Micromorphology of soils. London: Chapman and Hall Ltd., 1984. 432p. https://doi.org/10.1007/978-94-009-5544-8

MEDEIROS, R. A.; SCHALLER, H.; FRIEDMAN, G. M. Fácies Sedimentares: Análise e critérios para o reconhecimento de ambientes deposicionais. Trad. Carlos Walter Marinho Campos. Rio de Janeiro: Centro de Pesquisa e Desenvolvimento. Divisão de Documentação Técnica e Patentes da Petrobrás, 1971. 123p.

MELLO, C. L. Fácies sedimentares, arquitetura deposicional e relações morfoestratigráficas em um sistema de leques aluviais Holocênicos: Aloformação Manso Médio Vale do rio Paraíba do Sul (SP/RJ). 1992. 188p. Dissertação (Mestrado em Geologia) Universidade Federal do Rio de Janeiro, Rio de Janeiro.

NICHOLS, G. Sedimentology e stratigraphy. Londres: Blackwell Science, 1999. 355p.

NOWATZK, C. H.; SANTOS, M. A. A. dos; LEÃO, H. Z.; SCHUSTER, V. L. L.; WACKER, M. L. Glossário de estruturas sedimentares. Acta Geológica Leopoldensia, n. 18 e 19, ano VIII, p. 7-432, 1984.

OLIVEIRA, M. A. T. ; PESSENDA, Luiz Carlos Ruiz ; BEHLING, Hermann ; LIMA, Gisele Leite de ; FERREIRA, Glaucia Maria dos Santos Silva . Registro de mudanças ambientais pleistocências e holocênicas em depósitos de cabeceiras de vale: Campo Alegre, Planalto Norte Catarinense (SC). Revista Brasileira de Geociências , v. 36, p. 474-487, 2006. https://doi.org/10.25249/0375$\underline{7536.2006363474487}$

OLIVEIRA, M. A. T. de; CAMARGO, G.; PAISANI, J.C.; CAMARGO FILHO, M. Caracterização paleohidrológica de estruturas sedimentares quaternárias através de análises macroscópicas e microscópicas: do registro sedimentar local aos indícios de mudanças globais. Pesquisas em 
Análise macroscópica e micromorfológica de estruturas sedimentares aplicada à interpretação de eventos de deposição de sedimentos em depósitos de baixa encosta no sul do segundo planalto do estado Paraná (Brasil)

Geociências, Porto Alegre, v 28, n.2, p 183-195, 2001. https://doi.org/10.22456/1807$\underline{9806.20293}$

PAISANI, J. C. Descontinuidades hidrológicas, escoamento superficial e desenvolvimento de incisões erosiva em áreas de cabeceira de drenagem: estudo de caso na Colônia Quero-Quero, Palmeira (PR). 184p. Dissertação (Mestrado em Geografia) Universidade Federal de Santa Catarina, Florianópolis, 1998.

PETTIJOHN, F. J. Rocas Sedimentarias. 2. ed. Trad. Juan Turner. Buenos Aires: Editorial Universitaria de Buenos Aires, 1963.

PICARD, M. D.; HIGH JUNIOR, L. R. Sedimentary structures of ephemeral streams. Developments in Sedimentology, n. 17, Amsterdam, 1973. 223p.

PIETROBELLI, G. Estratigrafia e sedimentologia de depósitos de encosta no sul do Segundo Planalto do Paraná. In: XI Simpósio de Geologia do Sudeste, 2009, São Pedro. Anais do XI Simpósio de Geologia do Sudeste. Rio Claro, 2009. p. 153-153.

REINECK, H. E.; SINGH, I. B. Depositional Sedimentary Environments. Berlim:SpringerVerlag, 1980. 543p. https://doi.org/10.1007/978-3-642-81498-3

SELBY, M. J. Hillslope sediment transport and deposition. In: PYE, K. (Ed.) Sediment transport and depositional processes. London: Blackwell Scientific Publications, 1994. 397p.

SELLEY, R. C. Applied sedimentology. Londres: Academic Press Limited, 1988. 446p.

SUGUIO, K. Dicionário de Geologia Sedimentar e Áreas Afins. Rio de Janeiro: Bertrand Brasil, 1998. 1.222p.

SUGUIO, K. Geologia Sedimentar. Rio de Janeiro: Bertrand Brasil, 2003. 400p.

SUGUIO, K. Introdução à Sedimentologia. São Paulo: Edgard Blücher, 1973. 280p.

SUGUIO, K. Rochas Sedimentares, São Paulo: Edgard Blücher, 1980. 500p.

SUGUIO, K.; BIGARELLA, J. J. Ambiente fluvial. Curitiba: Ed. da UFPR-ADEA, 1979, 183p.

Recebido em: 25/02/2019

Aceito para publicação em: 09/09/2019 